\title{
PENGARUH PENGGUNAAN LIMBAH KULIT KOPI TERFERMENTASI (Aspergillus niger) DENGAN ARAS BERBEDA DALAM RANSUM TERHADAP PERTUMBUHAN AYAM BURAS
}

\author{
N. M. INTAN W. Y. K., I M. MASTIKA, DAN I M. NURIYASA \\ Program Studi Magister Ilmu Peternakan, \\ Fakultas Peternakan, Universitas Udayana, Denpasar \\ JL. P. B. Sudirman. Denpasar, Bali \\ e-mail: intankendran@yahoo.com
}

\begin{abstract}
ABSTRAK
Penelitian bertujuan untuk mengetahui potensi ransum yang mengandung limbah kulit kopi terfermentasi dengan Aspergillus niger dan non fermentasi terhadap pertumbuhan ayam buras. Rancangan yang digunakan dalam penelitian ini ialah rancangan acak lengkap (RAL) dengan lima perlakuan ransum dan lima ulangan sehingga terdapat 25 unit percobaan dan setiap unit terdiri dari empat ekor ayam. Perlakuan terdiri dari ransum tanpa menggunakan kulit kopi $\left(\mathrm{R}_{\mathrm{o}}\right)$, ransum menggunakan kulit kopi non fermentasi $10 \%\left(\mathrm{R}_{1}\right)$, ransum menggunakan kulit kopi non fermentasi 20\% $\left(\mathrm{R}_{2}\right)$, ransum menggunakan kulit kopi fermentasi $10 \%\left(\mathrm{R}_{3}\right)$, dan ransum menggunakan kulit kopi ferementasi $20 \%\left(\mathrm{R}_{4}\right)$. Variabel yang diamati performans yang meliputi bobot badan akhir, pertambahan bobot badan, konsumsi ransum, konversi ransum dan konsumsi air minum serta karakteristik karkas. Berdasarkan hasil penelitian dapat disimpulkan bahwa ayam buras jantan yang diberikan ransum dengan dengan tambahan limbah kulit kopi fermentasi dan non fermentasi sampai level 20\% tidak berpengaruh terhadap pertumbuhan ayam buras umur 3-11 minggu, namun terdapat kecenderungan bahwa pertumbuhan terbaik pada pemberian $10 \%$ kulit kopi fermentasi.
\end{abstract}

Kata kunci: limbah kulit kopi, ayam buras, performan

\section{THE EFFECT OF COFFEE SKIN WASTE FERMENTATION (ASPERGILLUS NIGER) WITH DIFFERENT LEVEL IN DIET TO THE GROWTH OF KAMPUNG CHICKEN}

\begin{abstract}
An experiment was carried out to study the effect of fermented and not fermented coffee skin waste to the growth of kampong chicken. A completely randomized design, with five treatments and five replications were used so there are 25 experiment units and each unit consisted of 4 cockerels. The Treatments as of Po: diet without coffee skin waste (diet control), P1: diet containing non fermented coffee skin waste 10\%, P2: diet containing non fermented coffee skin waste $20 \%, \mathrm{P}_{3}$ : diet containing fermented coffee skin waste $10 \%$ and $\mathrm{P}_{4}$ : diet containing fermented coffee skin waste $20 \%$. The variables measured were performance including the final body weight, weight gain, feed consumption, feed conversion ratio, water consumption, and carcass characteristics. Based on result,it can be concluded that kampong chicken given diet with additional fermented and non fermented coffee skin waste up to $20 \%$ level has no effect on the growth of kampong chicken age 3-11 weeks, but there is a tendency that the best diet is10\% fermented coffee skin.
\end{abstract}

Keywords: coffee skin waste, native chicken, performance

\section{PENDAHULUAN}

Permasalahan yang dihadapi peternak ayam buras untuk memperbaiki produktivitas ternak saat ini adalah mahalnya biaya pakan. Hal ini sesuai dengan pendapat Nataamijaya et al. (1988) yang menyatakan bahwa total biaya produksi tercermin dari sangat besarnya proporsi biaya untuk pakan yang nilainya mencapai $70 \%$. Menurut Mastika (1991) salah satu alternatif untuk penyediaan pakan yang murah dan tidak ada kompetisi dengan manusia melalui pemanfaatan limbah, baik limbah pertanian, limbah peternakan maupun limbah industri pertanian.

Pemakaian kulit kopi sebagai pakan ternak 
menopang terjadinya pemakaian sumberdaya terbarukan (renewable resources) dan tidak akan ada bahan yang terbuang (zero waste) dari suatu usaha dan meminimalkan input dari luar. Pemanfaatan limbah kulit kopi terfermentasi sebagai bahan pakan ternak ayam buras merupakan salah satu upaya yang dapat dilakukan dalam penyediaan pakan ternak. Potensi limbah kulit kopi dapat ditingkatkan nutriennya melalui proses fermentasi dengan Aspergillus niger (Budiari, 2014). Zaenudin dan Murtisari (1995) menyatakan, limbah kulit kopi memiliki kandungan protein kasar 10,4\%, kandungan ini hampir sama dengan protein yang terdapat pada bekatul dan memiliki kandungaan energi metabolis $3.356 \mathrm{kkal} / \mathrm{kg}$. Pakan ayam pedaging dengan kandungan kulit kopi sebanyak 5\% tidak berpengaruh negatif terhadap produktivitas ayam. Arora (1989) menyatakan bahwa pemberian dedak halus hingga 15\% pada pakan broiler jantan periode finisher dapat digantikan oleh kulit kopi, walaupun ada kecenderungan menurunnya konsumsi ransum, pertambahan berat badan, efisiensi penggunaan makanan dan persentase karkas. Penelitian oleh Hutabarat (2007) mendapatkan bahwa pemberian kulit buah kopi terfermentasi dengan Aspergilus niger sampai 10\% dalam ransum masih dapat diberikan kepada ayam buras karena tidak menunjukkan perbedaan pada pertambahan berat badan, konsumsi ransum, dan konversi ransum.

Melihat kondisi tersebut, maka perlu dilakukan penelitian untuk mengetahui produktivitas ayam buras pertumbuhan pada umur 3-11 minggu yang diberikan ransum mengandung kulit kopi terfermentasi (Aspergillus niger) dan non fermentasi dengan aras yang berbeda.

\section{MATERI DAN METODE}

\section{Ayam Buras}

Ayam buras yang digunakan dalam penelitian ini adalah ayam buras jantan umur 3 minggu dengan rata-rata bobot badan 169,5 g yang dilakukan di Stasiun Penelitian, Fakultas Peternakan Universitas Udayana, Sesetan, Denpasar untuk pemeliharaan dan pemotongan yang berlangsung selama 8 minggu.

\section{Kandang}

Kandang yang digunakan dalam penelitian ayam buras ini adalah kandang system "battery colony" terdiri dari 25 buah yang dindingnya terbuat dari kawat. Masing-masing kandang dilengkapi dengan tempat pakan dan minum yang diletakkan di sisi depan kandang. Tempat minum diletakkan di dalam bilik kandang. Setiap petak berukuran panjang $65 \mathrm{~cm}$, lebar $50 \mathrm{~cm}$, dan tinggi $75 \mathrm{~cm}$.

Ransum dan Air Minum
Ransum yang digunakan dalam penelitian ini diberikan pada ternak dalam bentuk mash dengan kandungan protein kasar 16,5\% dan energi termetabolis $2.850 \mathrm{kkal} / \mathrm{kg}$ (Scott et al. 1982), terdiri dari 5 jenis formula ransum sesuai dengan perlakuan. Pemberian ransum dilakukan dua kali sehari yaitu pada pagi hari dan pada sore hari yang diberikan secara ad libitum, pemberian air minum juga diberikan secara ad libitum.

Tabel 1. Susunan bahan-bahan ransum ayam buras yang dipergunakan dalam penelitian

\begin{tabular}{lrrrrr}
\hline \multirow{2}{*}{ Bahan } & \multicolumn{5}{c}{ Perlakuan (\%) } \\
\cline { 2 - 6 } & \multicolumn{1}{c}{ R0 } & \multicolumn{1}{c}{ R1 } & \multicolumn{1}{c}{ R2 } & R3 & \multicolumn{1}{c}{ R4 } \\
\hline Jagung kuning & 52.08 & 47.89 & 43.69 & 47.43 & 43.88 \\
Dedak padi & 25.97 & 19.92 & 13.87 & 22.81 & 19.08 \\
Kedelai & 14.75 & 14.99 & 15.24 & 13.56 & 10.86 \\
Tepung ikan & 6.00 & 6.00 & 6.00 & 5.00 & 5.00 \\
Limbah kulit kopi & 0 & 10.00 & 20.00 & 0 & 0 \\
Limbah kulit kopi terfermentasi & 0 & 0 & 0 & 10.00 & 20.00 \\
Premix & 0.20 & 0.20 & 0.20 & 0.20 & 0.20 \\
Grit & 1.00 & 1.00 & 1.00 & 1.00 & 1.00 \\
& 100,0 & 100,0 & 100,0 & 100,0 & 100,0 \\
\hline \multicolumn{1}{c}{ Total } & & & &
\end{tabular}

\section{Performa}

Variabel performa yang diamati dalam penelitian ini meliputi: bobot badan akhir, pertambahan bobot badan harian, konsumsi ransum, konversi ransum, konsumsi air minum, dan karakteristik karkas. Bobot badan akhir didapatkan dari penimbangan bobot ayam buras pada akhir penelitian.

\section{Karkas}

Karkas merupakan hasil utama pemotongan ternak yang memiliki nilai ekonomis tinggi (Soeparno, 1992). Karkas adalah bagian tubuh ayam tanpa bulu, darah, leher, kaki bagian bawah (cakar), dan viscera (Ensminger, 1980). Anonim (1995) menjelaskan karkas ayam pedaging adalah bagian tubuh ternak hidup setelah dikurangi bulu, dikeluarkan darah, jeroan, dan lemak abdominalnya, dipotong kepala dan leher serta kedua kakinya (ceker).

\section{Rancangan Percobaan}

Rancangan yang digunakan adalah rancangan acak lengkap (RAL) yang terdiri dari 5 perlakuan. Masingmasing perlakuan diulang sebanyak 5 kali sehingga terdapat 25 unit percobaan. Masing-masing unit percobaan menggunakan empat ekor ayam jantan sehingga jumlah ayam yang dipergunakan sebanyak 100 ekor. Kelima perlakuan tersebut adalah ransum tidak menggunakan limbah kulit kopi $\left(\mathrm{R}_{\mathrm{o}}\right)$, ransum menggunakan $10 \%$ limbah kulit kopi non fermentasi $\left(\mathrm{R}_{1}\right)$, ransum menggunakan 20\% limbah kulit kopi non fermentasi $\left(R_{2}\right)$, ransum menggunakan $10 \%$ limbah 
Tabel 2. Komposisi Kimia dalam ransum ayam buras

\begin{tabular}{|c|c|c|c|c|c|c|}
\hline \multirow{2}{*}{ Zat-zat makanan } & \multicolumn{5}{|c|}{ Perlakuan ${ }^{1)}$} & \multirow{2}{*}{$\begin{array}{c}\left.\text { Standard }{ }^{2}\right) \\
\text { (Scott et al, 1982) }\end{array}$} \\
\hline & RO & R1 & R2 & R3 & R4 & \\
\hline ME (Kkal/kg) & $2.850,03$ & $2.850,11$ & $2.850,20$ & $2.850,00$ & $2.850,07$ & 2.850 \\
\hline Protein (\%) & 16,50 & 16,50 & 16,50 & 16,50 & 16,50 & 16,5 \\
\hline Serat kasar (\%) & 4,92 & 6,00 & 7,07 & 5,69 & 6,34 & $3,00-8,00$ \\
\hline Lemak kasar (\%) & 5,88 & 5,13 & 4,38 & 5,32 & 4,78 & 4,00 \\
\hline Kalsium (\%) & 1,16 & 1,18 & 1,15 & 1,14 & 1,18 & 1,00 \\
\hline Fosfor (\%) & 0,62 & 0,54 & 0,45 & 0,61 & 0,60 & 0,41 \\
\hline Arginin (\%) & 1,28 & 1,18 & 1,08 & 1,14 & 0,99 & 0,85 \\
\hline Histidin (\%) & 0,46 & 0,42 & 0,38 & 0,41 & 0,36 & 0,41 \\
\hline Isoleusin (\%) & 0,87 & 0,82 & 0,77 & 0,77 & 0,68 & 0,91 \\
\hline Leusin (\%) & 1,75 & 1,62 & 1,50 & 1,56 & 1,39 & 1,36 \\
\hline Lisin (\%) & 1,05 & 1,00 & 1,00 & 0,92 & 0,82 & 1,14 \\
\hline Methionin (\%) & 0,36 & 0,33 & 0,31 & 0,31 & 0,28 & 0,41 \\
\hline Treonin (\%) & 0,75 & 0,79 & 0,65 & 0,66 & 0,59 & 0,73 \\
\hline Triptophant (\%) & 0,20 & 0,19 & 0,18 & 0,17 & 0,15 & 0,20 \\
\hline Tyrosin (\%) & 0,67 & 0,61 & 0,56 & 0,60 & 0,52 & 0,54 \\
\hline Valin (\%) & 0,91 & 0,84 & 0,77 & 0,81 & 0,71 & 0,73 \\
\hline
\end{tabular}

Keterangan:

1) Perlakuan RO: Ransum kontrol

Perlakuan R1: Ransum yang mengandung $10 \%$ limbah kulit kopi non fermentasi

Perlakuan R2: Ransum yang mengandung $20 \%$ limbah kulit kopi non fermentasi

Perlakuan R3: Ransum yang mengandung $10 \%$ limbah kulit kopi terfermentasi

Perlakuan R4: Ransum yang mengandung $20 \%$ limbah kulit kopi terfermentasi

2) Standar Scott et al. (1982)

kulit kopi terfermentasi $\left(\mathrm{R}_{3}\right)$, dan ransum menggunakan $20 \%$ limbah kulit kopi terfermentasi $\left(\mathrm{R}_{4}\right)$.

\section{Analisis Statistik}

Data hasil penelitian akan ditabulasi selanjutnya dianalisis dengan sidik ragam dan apabila didapatkan hasil yang berbeda nyata maka dilanjutkan dengan uji jarak berganda Duncan (Steel dan Torrie, 1993).

\section{HASIL DAN PEMBAHASAN}

\section{Bobot Badan Ayam}

Hasil peneltian menunjukkan tidak terdapat perbedaan yang nyata $(\mathrm{P}>0,05)$ pada variabel bobot badan awal ayam buras. Rataan bobot badan awal, bobot badan akhir, konsumsi ransum, pertambahan bobot badan harian, konversi ransum dan konsumsi air minum disajikan pada Tabel 3. Bobot badan awal ayam buras yang diberikan $\mathrm{R}_{0}, \mathrm{R}_{1}, \mathrm{R}_{2}, \mathrm{R}_{3}$ dan $\mathrm{R}_{4}$ masingmasing $169,60 \mathrm{~g}, 169,60 \mathrm{~g}, 169,55 \mathrm{~g}, 169,60 \mathrm{~g}$, dan 169,40 g (Tabel 1). Hal ini menunjukkan bahwa ayam buras yang digunakan pada penelitian ini memiliki bobot badan yang homogen, sehingga sesuai dengan rancangan yang digunakan.

Ayam buras yang mendapatkan perlakuan ransum $\mathrm{R}_{\mathrm{o}}$ menghasilkan bobot badan akhir paling tinggi yaitu 646,20 g (Tabel 3). Hal ini disebabkan karena pada perlakuan $R_{0}$ mengkonsumsi ransum paling tinggi dibandingkan perlakuan lain. Sesuai dengan

pendapat Soeharsono (1976) yang menyatakan bahwa konsumsi ransum mempunyai implikasi terhadap konsumsi zat nutrien dan akan berpengaruh terhadap laju pertumbuhan yang dimanifestasikan dalam bobot badan akhir dan pertambahan bobot badan. Perlakuan ransum $\mathrm{R}_{\mathrm{O}}$ menghasilkan bobot badan akhir lebih tinggi dibandingkan perlakuan $R_{2}$ secara statistik berbeda nyata $(\mathrm{P}<0,05)$ yang disebabkan karena kandungan serat kasar pada perlakuan $R_{2}$ (7,07\%) lebih tinggi dibandingkan perlakuan lain.

\section{Pertambahan Bobot Badan Ayam}

Pertambahan bobot badan ayam buras dari lima perlakuan menunjukkan bahwa perlakuan $\mathrm{R}_{\mathrm{o}}$ menghasilkan pertambahan bobot badan yang lebih tinggi yaitu 8,51 g (Tabel 3). Pada perlakuan $\mathrm{R}_{\mathrm{o}}$ lebih tinggi daripada perlakuan $\mathrm{R}_{2}$ secara statistik berbeda nyata $(\mathrm{P}<0,05)$. Penggunaan limbah kulit kopi fermentasi dan non fermentasi tidak mengubah kandungan nutrien ransum sehingga konsumsi ransum pakan tidak berbeda. Secara kualitiatif konsumsi ransum ayam buras yang diberi perlakuan $\mathrm{R}_{\mathrm{o}}$ lebih tinggi dibandingkan perlakuan lain. Hal ini disebabkan pada perlakuan ransum $\mathrm{R}_{\mathrm{o}}$ mengandung serat kasar paling rendah (4,92\%), sehingga konsumsi ransum ayam perlakuan $\mathrm{R}_{\mathrm{O}}$ lebih tinggi dibandingkan perlakuan lain. Konsumsi ransum yang lebih tinggi akan berdampak kepada konsumsi energi dan konsumsi protein yang lebih tinggi karena ransum dibuat iso energi dan iso protein. Sesuai dengan pendapat Tillman et al. (1986) bahwa makin tinggi konsumsi nutrien pada ternak maka pertumbuhan semakin meningkat.

Pada perlakuan $R_{2}$ peningkatan bobot badan yang lebih rendah dari perlakuan lainnya. Menurut 
Tabel 3. Performa ayam buras yang diberikan ransum mengandung limbah kulit kopi terfermentasi

\begin{tabular}{|c|c|c|c|c|c|c|}
\hline \multirow{2}{*}{ Variabel } & \multicolumn{5}{|c|}{ Perlakuan } & \multirow{2}{*}{ SEM } \\
\hline & $\mathrm{R}_{0}$ & $\mathrm{R}_{1}$ & $\mathrm{R}_{2}$ & $\mathrm{R}_{3}$ & $\mathrm{R}_{4}$ & \\
\hline Bobot badan awal (g) & $169,60^{\mathrm{a}}$ & $169,60^{\mathrm{a}}$ & $169,55^{a}$ & $169,60^{a}$ & $169,40^{a}$ & 0,12 \\
\hline Bobot badan akhir (g) & $646,20^{\mathrm{a}}$ & $557,10^{\mathrm{ab}}$ & $503,35^{b}$ & $599,99^{a b}$ & $584,15^{\mathrm{ab}}$ & 30,61 \\
\hline Pertambahan bobot badan(g/hari) & $8,51^{\mathrm{a}}$ & $6,92^{\mathrm{ab}}$ & $5,96^{\mathrm{b}}$ & $7,68^{a b}$ & $7,41^{\mathrm{ab}}$ & 0,55 \\
\hline Konsumsi ransum (g/hari) & $39,16^{\mathrm{a}}$ & $37,41^{\mathrm{a}}$ & $37,16^{a}$ & $37,45^{a}$ & $37,24^{a}$ & 0,75 \\
\hline Konversi ransum (FCR) & $4,71^{b}$ & $5,54^{\mathrm{ab}}$ & $6,72^{\mathrm{a}}$ & $4,99^{b}$ & $5,20^{\mathrm{b}}$ & 0,43 \\
\hline Konsumsi air (ml/hari) & $61,58^{a}$ & $56,69^{\mathrm{ab}}$ & $55,55^{b}$ & $60,01^{\mathrm{ab}}$ & $56,12^{\mathrm{ab}}$ & 1,82 \\
\hline
\end{tabular}

Keterangan:

1) R0: Ransum control; R1: ransum yang mengandung $10 \%$ kulit kopi non fermentasi; R2: ransum yang mengandung $20 \%$ kulit kopi non fermentasi; R3: ransum yang mengandung $10 \%$ kulit kopi terfermentasi; R4: ransum yang mengandung $20 \%$ kulit kopi terfermentasi

2) Superskrip yang sama pada baris yang sama menunjukan perbedaan yang tidak nyata $(P>0,05)$ dan superskrip berbeda pada baris yang sama menunjukan perbedaan yang nyata $(\mathrm{P}<0,05)$

3) SEM: Standard Error of the Treatment Means

Tillman et al. (1998), bahwa pertambahan bobot tubuh berhubungan dengan konsumsi ransum, semakin tinggi konsumsi ransum maka bobot tubuhnya akan semakin tinggi, sebaliknya semakin rendah konsumsi ransum maka bobot tubuhnya semakin kecil. Pertambahan bobot badan ayam buras antara perlakuan Ro (ransum kontrol) lebih tinggi dibandingkan perlakuan lainnya hal ini dikarenakan konsumsi ransum Ro paling tinggi dan FCR yang dihasilkan paling rendah.

\section{Konsumsi Ransum}

Konsumsi ransum ayam buras dari lima perlakuan menunjukkan bahwa $R_{0}$ yaitu 39,16 g/hari (Tabel 3), hal ini disebabkan karena penggunaan limbah kulit kopi terfermentasi dan non fermentasi sampai aras 20\% tidak menyebabkan perbedaan kandungan energi dan protein dalam ransum sehingga konsumsi ransum tidak berbeda. Kandungan serat kasar pada perlakuan $R_{2}$ tersebut paling tinggi (7,07\%) dibandingkan perlakuan lainnya yang mempengaruhi terhadap rendahnya konsumsi ransum. Kandungan serat kasar yang tinggi merupakan faktor pembatas utama pemanfaatan limbah sebagai bahan pakan bagi ternak nonruminansia, kandungan serat kasar dan lignin yang tidak mampu dicerna oleh unggas, berbeda dengan ruminansia yang mampu memanfaatkan selulosa sebagai sumber energi utama. Semakin tinggi level penggunaan limbah kulit kopi dalam ransum mengakibatkan semakin rendahnya tingkat konsumsi ransum. Hal ini diduga karena kandungan nutrisi ransum perlakuan $\mathrm{R}_{2}$ dalam imbangan yang hampir sama namun pada kulit buah kopi mengandung zat anti nutrisi yaitu tannin dan kafein yang mungkin tidak palatabel bagi ternak (Hutabarat, 2007). Salah satu yang mempengaruh konsumsi adalah palatabilitas (tingkat kesukaan ternak) jenis makanan yang diberikan (Charray et al,1992).

\section{Feed Conversion Ratio}

Pada akhir penelitian ayam buras yang mendapatkan perlakuan $\mathrm{R}_{\mathrm{O}}$ menghasilkan konversi ransum yang lebih rendah 4,71. Konversi ransum merupakan perbandingan antarajumlah konsumsi ransum dan pertambahan bobot badan. Hal ini sesuai dengan penelitian yang dilakukan oleh Hutabarat (2007) menyatakan bahwa pemberian kulit buah kopi fermentasi dengan Aspergilus niger aras 10\% masih dapat diberikan kepada ayam buras, karena tidak menunjukkan perbedaan pada pertambahan berat badan, konsumsi ransum, dan konversi ransum. Berdasarkan hasil penelitian pada konsumsi ransum perlakuan $\mathrm{R}_{2}$ yang tidak menunjukkan perbedaan yang nyata namun pertambahan bobot badan perlakuan $R_{2}$ yang dihasilkan paling rendah yang mengakibatkan FCR perlakuan $R_{2}$ paling tinggi. Pada perlakuan ransum yang menggunakan kulit kopi non fermentasi $20 \%\left(\mathrm{R}_{2}\right)$ menghasilkan perbedaan yang nyata paling tinggi sesuai dengan yang dikemukakan oleh AAK (1988) bahwa angka konversi ransum menunjukkan tingkat efisiensi dalam penggunaan ransum. Jika angka konversi ransum semakin besar, maka penggunaan ransum tersebut kurang efisien yang akan berpengaruh terhadap pertumbuhan.

Konsumsi air minum pada akhir penelitian menunjukkan bahwa pada perlakuan $\mathrm{R}_{\mathrm{O}}$ mengkonsumsi air paling tinggi yaitu $61,58 \mathrm{ml}$ (Tabel 3). Hal ini disebabkan konsumsi ransum pada perlakuan $R_{0}$ paling tinggi sehingga konsumsi air minum juga meningkat. Konsumsi pakan erat kaitannya dengan konsumsi air minum yaitu 2-2,5 kali dari jumlah pakan. Pada perlakuan $\mathrm{R}_{2}$ konsumsi ransum paling rendah dibandingkan perlakuan lain, dimana akan berpengaruh terhadap konsumsi air minum. Sejalan dengan yang dikemukakan Tillman et al. (1986) yang menyatakan bahwa makin tinggi konsumsi ransum maka mempengaruhi peningkatan pada konsumsi air yang makin tinggi.

Hasil penelitian terhadap rataan bobot potong, bobot karkas, dan persentase karkas ayam buras akibat penggunaan limbah kulit kopi dalam ransum ayam buras jantan tersaji pada Tabel 4. Rataan bobot potong ayam buras pada pemberian ransum $\mathrm{R}_{\mathrm{o}}$ lebih tinggi 
Tabel 4. Karkas ayam buras yang diberikan ransum yang mengandung limbah kulit kopi

\begin{tabular}{|c|c|c|c|c|c|c|}
\hline \multirow{2}{*}{ Variabel } & \multicolumn{5}{|c|}{ Perlakuan } & \multirow{2}{*}{ SEM } \\
\hline & $\mathrm{R}_{0}$ & $\mathrm{R}_{1}$ & $\mathrm{R}_{2}$ & $\mathrm{R}_{3}$ & $\mathrm{R}_{4}$ & \\
\hline Bobot potong (g) & $621,10^{a}$ & $598,05^{a}$ & $520,03^{b}$ & $615,12^{a}$ & $512,06^{a}$ & 19,16 \\
\hline Bobot karkas(g) & $359,05^{a}$ & $345,03^{a}$ & $281,11^{b}$ & $341,27^{a}$ & $279,08^{b}$ & 19,06 \\
\hline Persentase karkas(g) & $58,33^{a}$ & $58,70^{\mathrm{a}}$ & $54,21^{a}$ & $56,06^{a}$ & $54,41^{a}$ & 3,21 \\
\hline Persentase dada (g) & $21,97^{a}$ & $20,92^{a}$ & $22,96^{a}$ & $22,12^{a}$ & $21,91^{a}$ & 1,13 \\
\hline Persentase paha (g) & $16,59^{a}$ & $17,78^{a}$ & $16,61^{a}$ & $17,10^{a}$ & $17,04^{a}$ & 0,56 \\
\hline Persentase betis (g) & $19,41^{a}$ & $17,99^{a}$ & $18,18^{a}$ & $18,67^{a}$ & 18,09 & 0,65 \\
\hline Persentase sayap (g) & $15,40^{b}$ & $15,85^{a b}$ & $15,26^{b}$ & $15,98^{a b}$ & $16,86^{a}$ & 0,40 \\
\hline Persentase punggung (g) & $25,74^{a}$ & $25,43^{a}$ & $24,34^{a}$ & $23,36^{\mathrm{a}}$ & $25,39^{a}$ & 0,91 \\
\hline
\end{tabular}

Keterangan:

1) R0: Ransum control; R1: ransum yang mengandung 10\% kulit kopi non fermentasi; R2: ransum yang mengandung $20 \%$ kulit kopi non fermentasi; R3: ransum yang mengandung $10 \%$ kulit kopi terfermentasi; R4: ransum yang mengandung $20 \%$ kulit kopi terfermentasi

2) Superskrip yang sama pada baris yang sama menunjukan perbedaan yang tidak nyata $(P>0,05)$ dan superskrip berbeda pada baris yang sama menunjukan perbedaan yang nyata $(\mathrm{P}<0,05)$

3) SEM: Standard Error of the Treatment Means

yaitu 621 gram (Tabel 4). Kandungan serat kasar pada perlakuan $\mathrm{R}_{\mathrm{o}}$ paling rendah (4,92\%). Berkaitan dengan bobot potong yang erat sekali hubungannya dengan pertumbuhan. Pertumbuhan yang baik dipengaruhi oleh jenis pakan, komposisi kimia, dan konsumsi pakan sehingga dapat menghasilkan bobot potong yang maksimal. Hal ini disampaikan oleh Soeparno (2005) yang menyatakan konsumsi protein dan energi yang lebih tinggi akan menghasilkan laju pertumbuhan yang lebih cepat. Kondisi ini berkorelasi positif terhadap berat karkas dan persentase karkas. Selain itu ayam buras yang mendapat perlakuan ransum $\mathrm{R}_{\mathrm{o}}$ menunjukkan nilai konversi ransum yang paling rendah, hal ini mengindikasikan penggunaan ransum yang paling efisien.

Rataan bobot karkas pada ayam buras paling tinggi terjadi pada perlakuan $\mathrm{R}_{\mathrm{o}}$ yaitu 359,05 $\mathrm{g}$ (Tabel 4). Hal ini disebabkan karena konumsi ransum lebih tinggi dan FCR yang dihasilkan lebih rendah pada perlakuan Ro dibandingkan perlakuan lainnya. Karkas meningkat seiring dengan meningkatnya umur dan bobot badan. Akibat dari adanya perbedaan bobot karkas tersebut maka secara langsung akan berpengaruh terhadap tingkat perbedaan bobot potongan karkas (dada, paha dan sayap). Anggraeni (1999) menyatakan penurunan bobot karkas relatif konstan terhadap bobot hidup, sehingga meskipun bobot karkas turun persentasenya relatif tetap. Sesuai dengan pendapat Asnawi (1997) antara jumlah berat hidup ayam buras erat hubungannya dengan jumlah persentase karkas ayam buras. Hal ini juga dikemukakan oleh Jull (1972) bahwa persentase karkas ditentukan oleh besarnya bagian tubuh yang terbuang, seperti kepala, leher, jeroan, bulu, dan darah. Sesuai dengan pendapat Kamal (1994) yang menyatakan bahwa apabila bobot karkas yang didapatkan tidak berbeda nyata itu disebabkan karena bobot potong yang didapatkan juga berbeda tidak nyata.

Persentase karkas pada akhir penelitian, perlakuan dengan pemberian ransum $\mathrm{R}_{1}$ menunjukkan hasil yang paling tinggi yaitu 58,70\% (Tabel 4). Menurunnya persentase karkas seiring dengan bertambahnya jumlah pemberian kulit kopi non fermentasi diduga karena zat antinutrisi yang terkandung dalam kulit kopi yakni tanin dan kafein yang dapat menghambat pertumbuhan (Molina, 1974 dan Brahman, 1979 dalam Arora, 1989). Tandi (2010) mengemukakan tanin yang masuk ke dalam saluran pencernaan akan terikat dengan protein sehingga sulit dicerna oleh enzim protease mengakibatkan asam-asam amino sedikit terbentuk dan akan mempengaruhi pertumbuhan. Besarnya persentase karkas ditentukan oleh jumlah energi yang diperoleh ternak dari zat-zat makanan yang terkandung dalam bahan makanan.

Rataan potongan komersial karkas (dada, paha, dan sayap) ayam buras umur 11 minggu yang diberi pakan ransum mengandung limbah kulit kopi terfermentasi ditampilkan pada Tabel 2. Hasil analisis ragam menunjukkan bahwa pemberian limbah kulit kopi non fermentasi tidak berbeda nyata $(\mathrm{P}>0,05)$ mempengaruhi persentase karkas dan potongan karkas ayam buras umur 11 minggu. Penggunaan 10\% limbah kulit kopi terfermentasi tidak nyata $(\mathrm{P}>0,05)$ menghasilkan potongan karkas lebih tinggi dibandingkan dengan penggunaan 20\% limbah kulit kopi fermentasi. Penurunan persentase karkas dan potongan karkas ini berkaitan dengan semakin meningkatnya persentase serat kasar dalam ransum. Menurut Ketaren (2006), meningkatnya taraf serat kasar dalam ransum akan menurunkan kecernaan zat makanan. Konsumsi ransum yang menurun menyebabkan pembentukan komponen tubuh berkurang, akibatnya bobot atau persentase karkas dan potongan karkas juga menurun. Hasil penelitian menunjukan potongan karkas yang tinggi mempengaruhi bobot pada persentase dada yang tinggi. Keberadaan pakan sangat penting bagi ayam buras karena pakan mengandung zat-zat nutrisi 
yang dibutuhkan untuk pembentukan komponen karkas dan komponen tubuh yang lain (Rasyaf, 2000). Apabila ayam buras kekurangan pakan atau kebutuhan nutrisinya tidak tercukupi maka pembentukan karkas akan terhambat.

Penggunaan limbah kulit kopi non fermentasi dan fermentasi sebagai bahan penyusun ransum komplit tidak memberi pengaruh yang nyata terhadap persentase paha, dada dan sayap ayam buras umur 11 minggu (Tabel 2). Hal ini sesuai dengan pernyataan Natasasmita (1990), paha, dada dan sayap ayam buras menunjukkan kecepatan perkembangan yang sama dengan tubuh secara keseluruhan, dengan kata lain paha mempunyai pola pertumbuhan isogonik. Meningkatnya level penggunaan limbah kopi sebagai bahan penyusun ransum dalam ransum akan meningkatnya serat kasar, sehingga kecernaan ransum menurun. Demikian juga halnya penggunaan limbah kulit kopi non fermentasi dan fermentasi ransum komplit tidak memberi pengaruh yang signifikan terhadap persentase sayap.

\section{SIMPULAN}

Berdasarkan hasil penelitian diatas maka dapat disimpulkan bahwa ayam buras dapat diberikan limbah kulit kopi non fermentasi dan fermentasi dalam ransum sampai 20\% dan pemberian 10\% memberikan hasil terbaik.

\section{UCAPAN TERIMAKASIH}

Pada kesempatan ini kami mengucapkan banyak terimakasih kepada Rektor Universitas Udayana, Direktur Program Pasca Sarjana Universitas Udayana, Ketua Progran Studi Ilmu Peternakan, Program Pasca Sarjana, Universitas Udayana dan Dekan Fakultas Peternakan, Universitas Udayana bapak Dr. Ir. Ida Bagus Gaga Partama, MS atas pelayanan administrasi dan fasilitas pendidikan yang diberikan kepada penulis selama menjalani perkulihaan.

\section{DAFTAR PUSTAKA}

AAK, 1988. Budidaya Tanaman Kopi. Kanisius, Yogyakarta Anggraeni, 1999. Pertumbuhan Alometri dan Tinjauan Morfologi Serabut Otot Dada (Muscullus pectoralis dan Muscullus supsupracoracorideus) pada Itik dan Entok Lokal. Disertasi Program Pasca Sarjana Institut Pertanian Bogor.

Arora, S. P. 1989. Pencernaan Mikrobia Pada Ruminansia. Gadjah MadaUniversity Press, Yogyakarta.

Asnawi, 1997. Kinerja Pertumbuhan dan Fisiologi Ayam

Kampung dan Hasil Persilangannya Dengan Ayam Ras Tipe Pedaging. Tesis Magister Sains Program Pasca
Sarjana IPB. Bogor.

Bakrie, B., D. Andayani, M. Yanis, dan D. Zainuddin. 2003. Pengaruh Penambahan Jamu k dalam Air Minum terhadap Preferensi Konsumen dan Mutu Karkas Ayam Buras. hlm.490-495. Prosiding Seminar Nasional Teknologi Peternakan dan Veteriner "Iptek untukMeningkatkan Kesejahteraan Petani melaluiAgribisnis Peternakan yang Berdaya Saing”. Bogor, 29-30 September 2003. Pusat Penelitian dan Pengembangan Peternakan, Bogor.

Brake J., G.B. Havestein, S.E. Scheideler, P.R. Ferket and D.V. Rives.1993. Relationship of sex, age and bodyweight to broiler carcass yield and ofal production. Poult. Sci. 72: 1137-1145.

Budiari, N. M. 2014. "Pengaruh Aras Kulit Kopi Terfermentasi dalam Ransum terhadap Pertumbuhan Kelinci Lokal Jantan "Lepus negricollis" (Tesis). Denpasar: Universitas Udayana.

Charraym, J., J. M. Humbert, and J. Levif. 1992. Manual of Sheep Production in the Humid Tropic of Africa. CAB International. Wallingford, UK.

Ensminger, M. E. 1980. Dairy Cattle Science. $2^{\text {nd }}$ Ed., The Interstate Printers and Publishers, Inc. Illinois. USA. Pp. 169-443.

Hutabarat, 2007. Pengaruh limbah kulit kopi terfermentasi berbeda pada pakan buatan terhadap efisiensi pakan, pertumbuhan ayam buras. Journal of Aquaculture Management and Technology. 2(2): 26-36.

Jull, M. A. 1972. Poultry Husbandry. 2nd Ed, Tata Mc Graw Hill Book Publishing Co. Ltd., New Delhi. Javascript.

Kamal, M. 1986. Kontrol Kualitas Pakan dan Menyusun Ransum Ternak. Fakultas Pasca Sarjana, Universitas Gajah Mada.

Ketaren, P. P., 2006. Optimalisasi Pemanfaatan Wheat Bran Untuk Produksi Daging Unggas Melalui Suplementasi Enzim Xilanase dan Glukanase: Itik Pedaging. Prosiding. Seminar Nasional Bioteknologi. Cibinong, 15-16 November 2006. Puslit Bioteknologi, LIPI, Cibinong. hlm. 325-331.

Mastika, I M.1991 Potensi Limbah Pertanian dan Industri Pertanian Serta Pemanfatan nya untuk Makan Ternak. Denpasar. 25 September 1991. Pengukuhan Guru Besar Ilmu Makanan Ternak Pada Fakultas Peternakan Universitas Udayana, Denpasar.

Nataamidjaja, A.G 1998. Produktivitas Ayam Buras di Kandang Litter pada Berbagai Imbangan Kalori Protein. Prosiding Nasional Seminar Peternakan dan Forum Peternak Unggas dan Aneka Ternak II. Balai Penelitian Ternak, Bogor.

Natasasmita, A., 1990. Tumbuh Kembang pada Ternak. Buletin Penelitian Universitas Djuanda Bogor. 1 (1): 45-50.

Rasyaf, M. 200o. Beternak Ayam Buras. Penebar Swadaya: Jakarta. 
Scott, M.L., M.C. Nesheim, and R.S. Young. 1982. Nutrition of the Chickens. $3^{\text {ed }}$. Published by M.L. Scott \& Associates, Itacha, New York.

Soeharsono (1976). Respon Broiler terhadap Berbagai kondisi lingkungan. Disertasi, Universitas Pajajaran, Bandung.

Soeparno.1992. Komposisi Tubuh Dan Evaluasi Daging Dada Sebagai Pedoman Penilaian Kualitas Produk Ayam Buras jantan. Bulletin Peternakan 16:7-4.

Soeparno. 2005. Ilmu dan Teknologi Daging. Cetakan ke-4. Gadjah Mada University Press, Yogyakarta.

Steel, R. G. D. dan J. H. Torrie. 1993. Prisip dan Prosedur Statistika Suatu Pendekatan Biometrik. Ed. 2. PT GramediaPustaka Utama, Jakarta.

Tandi, E. J. 2010. Pengaruh Tanin Terhadap Aktivitas Protease. Seminal Nasional Teknologi Peternakan dan Veteriner. Fakultas Peternakan. Universitas Hasanud- din. Makassar. Hal: 567-570.

Tillman, A.D., H. Hartadi, S. Reksohardiprodja dan L. Soekamto. 1986. Ilmu Makanan Ternak Dasar. Gadjah Mada, University Press, Yogyakarta.

Tillman, A. D., H. Hartadi, S. Reksohadiprodjo, S. Prawiro Kusuma, dan S. Lebdosoekoekojo. 1998. Ilmu Makanan Ternak Dasar. Gadjah Mada University Press, Yogyakarta.

Zainuddin, D. dan T. Murtisari. 1995. Penggunaan Limbah Agro-Industri Buah Kopi (Kulit Buah Kopi) dalam Ransum Ayam Pedaging (Broiler). Pros. Pertemuan IImiah Komunikasi dan Penyaluran Hasil Penelitian. Semarang. Sub Balai Penelitian Klepu, Puslitbang Petemakan, Badan Litbang Pertanian, p. 71-78.

Zuprizal. 1993. Pengaruh penggunaan pakan tinggi protein terhadap penampilan karkas dan perlemakan ayam pedaging fase akhir. Buletin Peternakan 17:110 -118. 